\title{
Healing and hurting, all in one building in Mexico
}

$\mathrm{S}$ creams of terror can still be heard inside the massive 18thcentury stone building on Plaza de Santo Domingo in the heart of Mexico City. Don't let the screams deter you. Just walk in. Immediately to the right of the carved wooden door is a small chamber with benches built into limestone walls. This is where, three centuries ago, Dominican priests would sit and discuss the religious and political development of the country they called New Spain.

Today that tiny room contains a realistic looking replica of a human body in a glass box. The skin has been crudely stripped away in many places to reveal muscle, organs and a most hideous facial expression. First-time visitors might wonder which of the two museums inside the building owns this exhibit. It could be equally at home in either museum, which are seemingly unrelated but have more in common than they may want to admit.

Let's call the two cohabiting museums the Museum of Healing and the Museum of Hurting, although their real names are the Museum of Mexican Medicine and the Museum of the Inquisition. Both reside in the building christened in 1736 as the Palace of the Inquisition. Both museums are dedicated to teaching the public about two very different historical approaches to poking and prodding the human body.

The Museum of the Inquisition certainly has squatter's rights. The Dominicans were killing and torturing heretics in this neighbourhood for about 200 years before architect Pedro de Arrieta created the palace. The victims of the Inquisition in the palace were Jews, Protestants, Indians, homosexuals, uppity intellectuals and various heretics-du-jour. The torture cells were in the basement so screaming voices did not disturb Dominican prayers on upper floors.

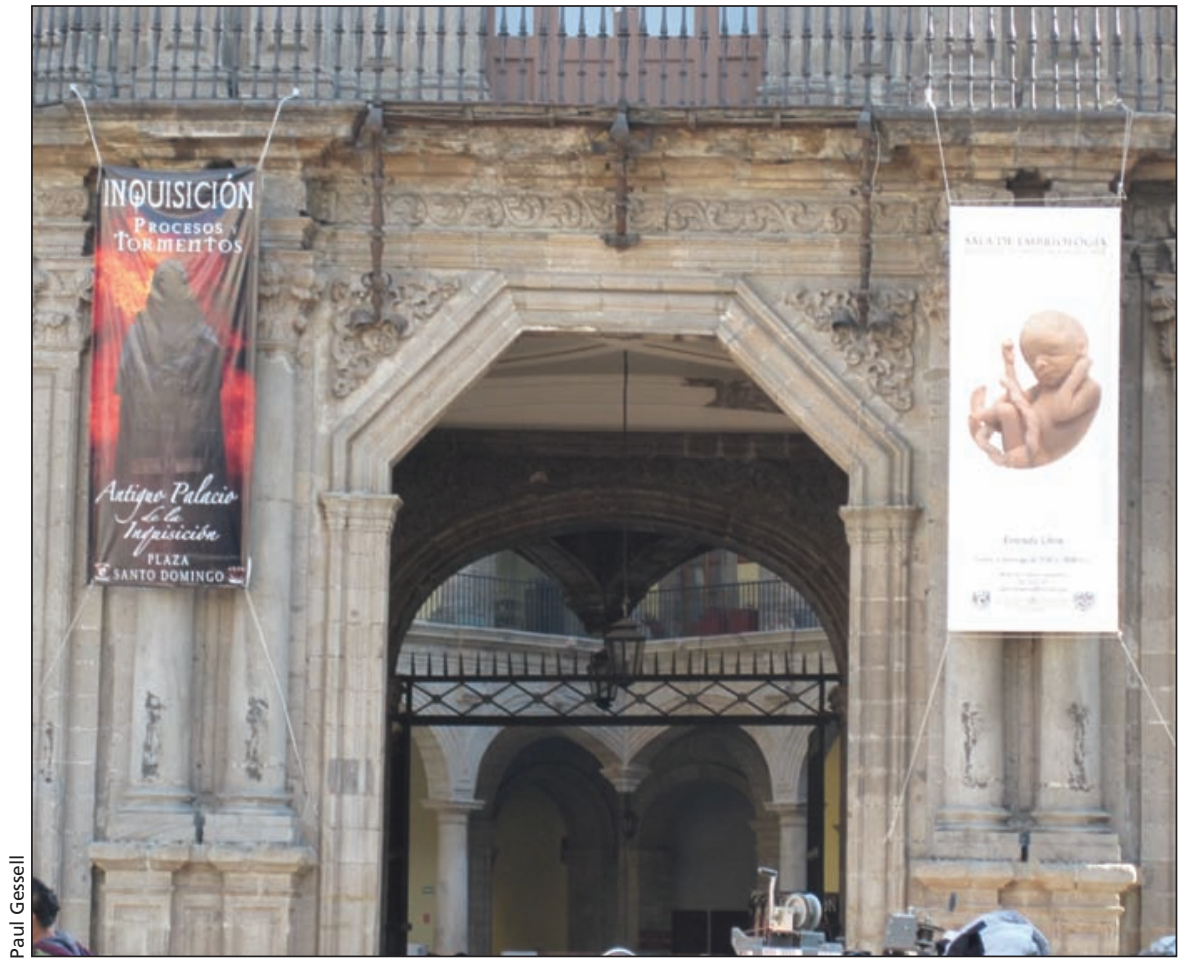

Street entrance to the Palace of the Inquisition.

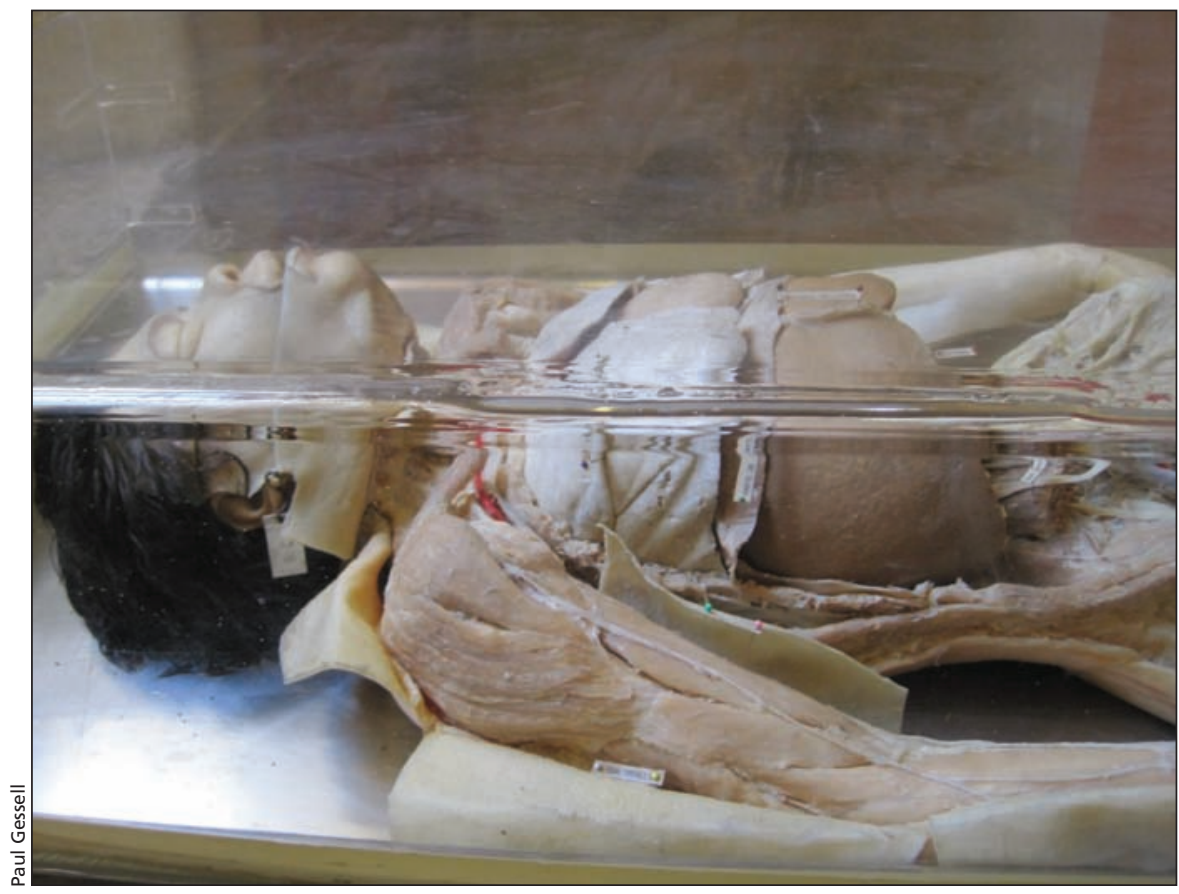

The flayed fake body on display at entrance to the Palace of the Inquisition. 


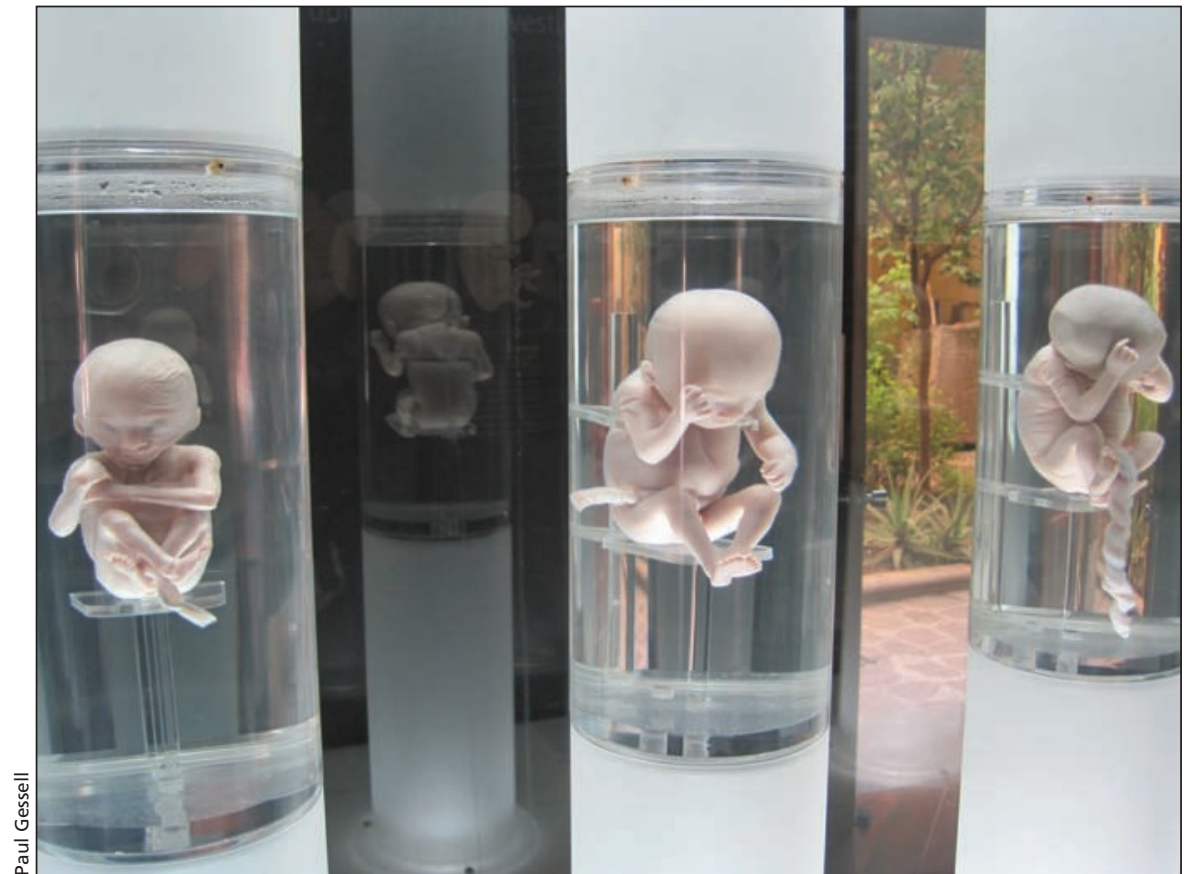

Part of the embryo exhibit.

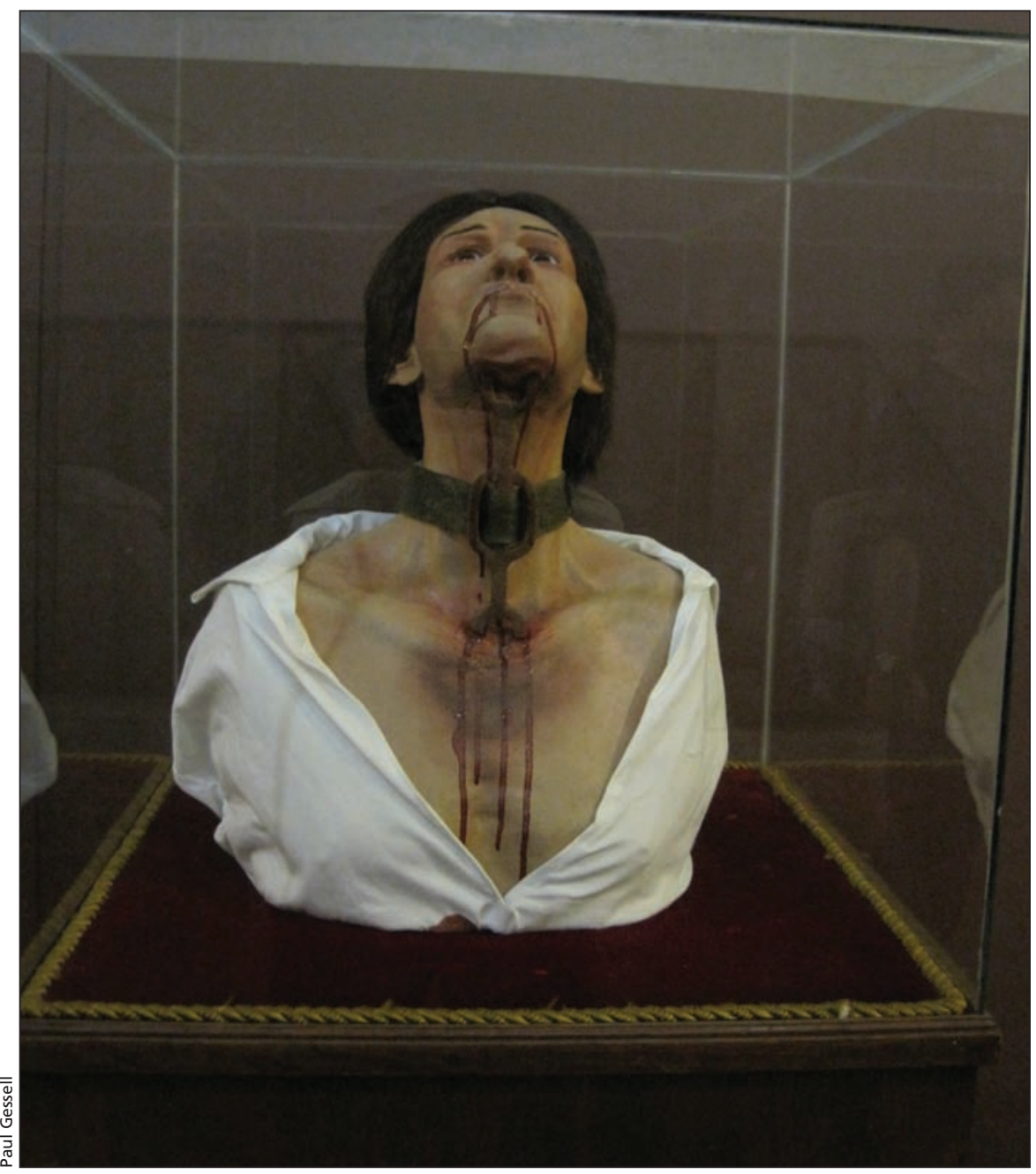

Display at the entrance to the Inquisition Museum.
The Inquisition ended in Mexico in 1820 and the palace went into a sort of swords-to-ploughshares transformation: The sharp, pointy tools used by priests to torment healthy body parts were gradually replaced by sharp, pointy tools used by physicians for treating diseased body parts. (Both sets of tools are exhibited.) The building became a medical school in 1837 and, since 1980, a medical museum affiliated with the university generally known by its acronym UNAM (Universidad Nacional Autónoma de México).

The two museums repeatedly cross paths in the building. For example, the interior courtyard leading to the privately run Museum of the Inquisition is lined with antique $\mathrm{x}$-ray machines that look like new-fangled versions of the racks used by the torturers to stretch bodies. Horrific dioramas with mannequins and videotaped theatrical recreations by screaming actors demonstrate just how the racks and other torture devices were used.

The exhibits in the medical museum examine domestic medical practices, treatments and implements from preHispanic days to the early 20th century. There is everything from a garden of ancient folk remedies to mock-ups of 19th-century doctors' offices, to a rather lurid display of plaster body parts with skin eruptions caused by various diseases.

Some of the folk medicine that originated with Aztecs, Zapotecas and other indigenous groups is still practised in some communities, both urban and rural. These precolonial remedies include such plants as flor de manita for helping diabetics, hojos de purgo for settling the stomach and toloache, a herb placed in soups that ensures the man consuming the broth falls in love with the cook.

The big hit at the medical museum is the ground floor exhibition of preserved embryos. Visiting school students invariably look shell-shocked as they robotically aim their cell phone cameras at each exhibit. What they see are all stages of development in the womb from fertilization to full-term fetuses. The eerily lit line-up of pickled scraps of life and miniature fetal skeletons has the look of a carefully arranged, albeit creepy, art installation. 
The staff of the Museum of the Inquisition previously dressed like the priests and nuns torturing heretics inside. No longer. But the staff remains preachy. No talking, the ticket man says sternly and repeatedly as he passes out Spanish-only audio guides. One is afraid to ask what happens if you do talk. Are you punished by becoming part of one of the dioramas of nearly nude mannequins having their feet burned, gallons of water forced down their throats and sharp objects thrust into sensitive places?

On exhibition is an ingenious device, a fork-like object with curved and sharpened tines. It's called both a cat's paw and a Spanish tickler. And it's perfect for shredding the skin of live heretics. So, is this what happened to the aforementioned flayed creature at the very front of the building? No. The realistic looking cadaver was created to teach doctors, not torturers. Perhaps the look of sheer terror on the cadaver's face is just some long-gone anatomy professor's little joke to frighten squeamish interns or perhaps to remind them of this building's dark history.

\section{Paul Gessell}

\section{Art critic}

Gatineau, Que.

The Palace of the Inquisition is located at 33 República de Brasil in Mexico City. The closest subway stops are Zócalo or Allende. The Museum of the Inquisition charges 50 pesos for adults and admission to the Museum of Mexican Medicine is free.

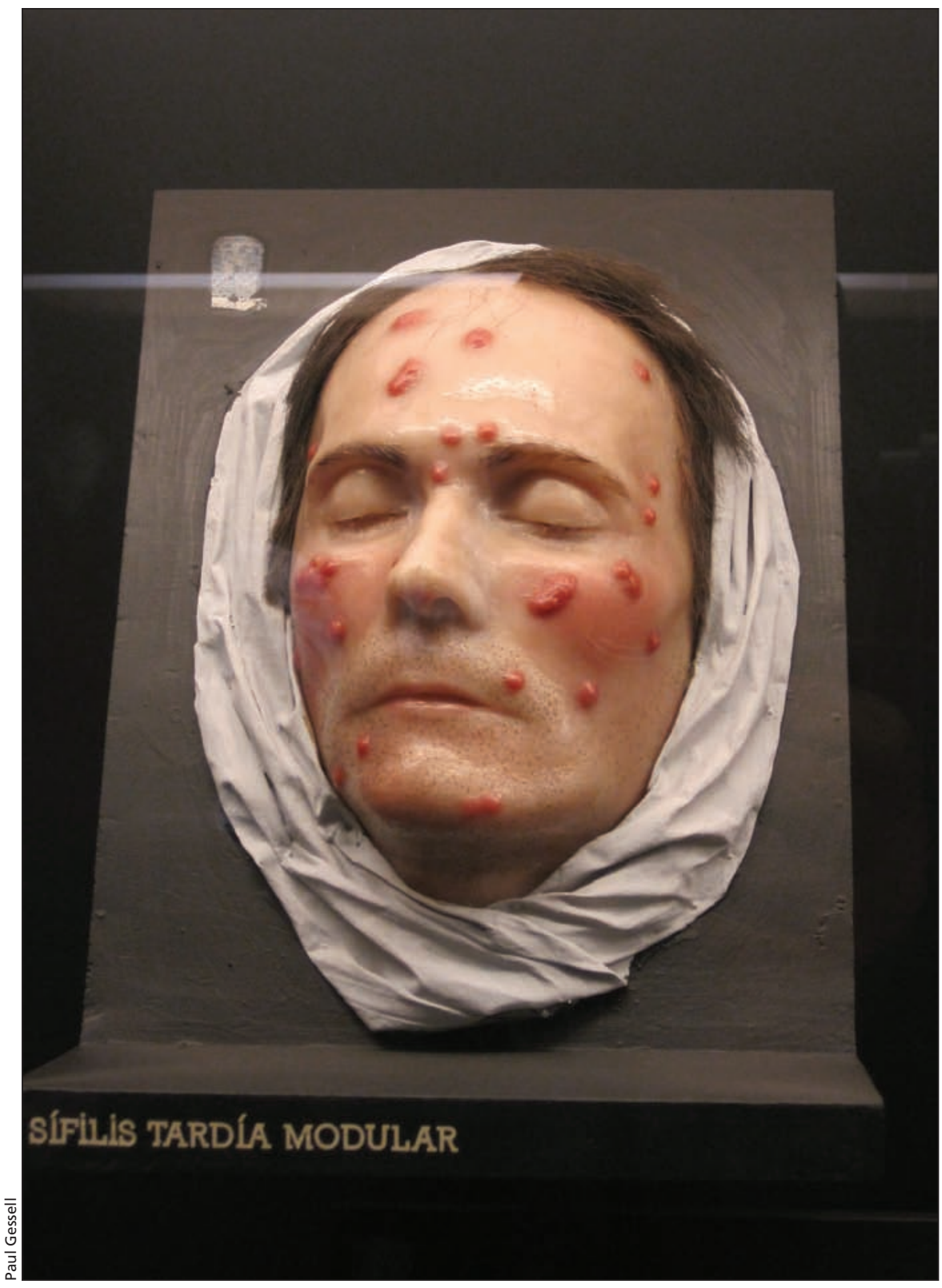

Display in the medical museum on diseases that cause skin eruptions. 